\title{
Polyglycolic acid/chitosan glue and apoptosis of endometriotic cells
}

\author{
Yu-Chi Wang, Ph.D., ${ }^{\mathrm{a}}$ Ru-Huei Fu, M.S., ${ }^{\mathrm{b}}$ Hsyue-Jen Hsieh, Ph.D., ${ }^{\mathrm{a}}$ \\ Hsiang-Tai Chao, M.D., Ph.D., ${ }^{\mathrm{c}}$ and Shu-Huei Kao, Ph.D. ${ }^{\mathrm{d}}$ \\ ${ }^{\mathrm{a}}$ Departments of Chemical Engineering and ${ }^{\mathrm{b}}$ Agriculture Chemistry, National Taiwan University; ${ }^{\mathrm{c}}$ Department of Obstetrics/ \\ Gynecology, Veterans General Hospital-Taipei; and ${ }^{\mathrm{d}}$ Graduate Institute of Biomedical Technology, Taipei Medical University, \\ Taipei, Taiwan
}

\begin{abstract}
Objective: To induce apoptosis of endometriotic cells of patients with endometriosis.
Design: To demonstrate that polyglycolic acid/chitosan glue directly inhibits cell proliferation by inducing apoptosis.

Setting: University hospital infertility center.

Patient(s): Twelve women who visited the center for infertility therapy.

Intervention(s): Polyglycolic acid/chitosan glue was applied into primary endometriotic cells; the manipulated cells were collected 1-4 days after polyglycolic acid/chitosan glue treatment.

Main Outcome Measure(s): Primary endometriotic cell cultures from eutopic endometriotic tissue were established. The effect of the novel biological glue, polyglycolic acid/chitosan glue A, on endometrial cells in vitro was examined. The different stages of apoptosis were analyzed using flow cytometry with fluorescein isothiocyanate conjugate (FITC)-annexin V and propidium iodide staining.

Result(s): The growth inhibitory effects of polyglycolic acid/chitosan glue A on endometrial cells were found to be dose-response and time dependent. Less than $15 \%$ viability was detected in cultures containing $2,000 \mu \mathrm{g}$ of polyglycolic acid/chitosan glue A after 4 days of treatment. Induced apoptosis and caspase activity were revealed. The caspase-3 activity increased 2.2-fold with 4 days of culture with 2,000 $\mu \mathrm{g}$ of polyglycolic acid/chitosan glue A. Conclusion(s): This is the first study to demonstrate that polyglycolic acid/chitosan glue directly inhibits cell proliferation by inducing apoptosis, thus suggesting that this new biological glue may be useful for endometriosis therapy. (Fertil Steril ${ }^{\circledR} 2005 ; 84: 75-81$. (C2005 by American Society for Reproductive Medicine.)
\end{abstract}

Key Words: Endometriosis, polyglycolic acid, chitosan, apoptosis

Endometriosis is described as the presence of endometrial tissue in locations outside the endometrial (uterine) cavity. Endometriosis is commonly found in the cul-de-sac (behind the uterus), the rectovaginal septum (the tissue between the rectum and the vagina), on the surface of the rectum, the fallopian tubes, ovaries, the uterosacral ligaments, the bladder, and the pelvic sidewall $(1,2)$. Generally, endometriosis in the rectovaginal septum is more likely to penetrate deeply into the underlying structures. In most cases, endometriotic cells can be found in the fluid behind the uterus of patients during menstruation. None of the mentioned theories seems to explain all cases. Unfortunately, we do not know its causes. The estimated worldwide population that suffers from endometriosis varies wildly; at least $10 \%$ of the female population suffers from the disease, which makes endometriosis one of the most common diseases affecting women's health (1-3).

Received August 16, 2004; revised and accepted January 10, 2005. Supported by research grant NSC89-2320-B264-006 from the National Science Council of the Republic of China.

Reprint requests: Shu-Huei Kao, Ph.D., Graduate Institute of Biomedical Technology, 250 Wu Hsing Street, Taipei Medical University, Taipei, Taiwan 110, R.O.C. (FAX: 886-2-27324510; E-mail: kaosh@ tmu.edu.tw)
Although there is no effective treatment for endometriosis, a variety of treatment options have been established. Several treatment goals include relief or reduction of pain, suppression of endometrial growth, safeguarding or restoration of fertility, and avoiding recurrence of the disease. Danazol (4), birth control pills, Zoladex, and Norplant have not proven effective as either primary or adjunctive therapy (combined with surgery) for endometriosis-related infertility. Medical treatments for endometriosis might cause inflammation; surgical correction has fewer side effects and is mainly used to reduce endometriosis-related pain.

Endometriosis and cancer are similar in several aspects such as cell invasion, unrestrained growth, development of new blood vessels, and a decrease in the number of cells undergoing apoptosis. Endometriotic cells were identified with lower susceptibility to apoptosis and more surviving genes (5). Surviving may antagonize caspase-3-mediated apoptosis and subsequently promote the development of endometriosis (6).

In this study, growth inhibition effects of a new type of biological glue composed of polyglycolic acid (PGA) on cultured endometrial cells were observed. This biological glue was designed and processed with two significant characteristics: biodegradability and cell growth inhibition $(7,8)$. 
Two types of biodegradable biomaterials, chitosan and PGA polymer, are used as ingredients of the glue. By using PGA, we can easily manipulate the biodegradation rate, and chitosan inhibits the growth of tumor-like cells. Chitosan is a binary polyheterosaccharide of $N$-acetylglucosamine and glucosamine with a $\beta 1 \rightarrow 4$ linkage. This polyheterosaccharide structurally resembles glycosaminoglycans consisting of long-chain, unbranched, repeating disaccharide units $(9-11)$. Chitosan was previously demonstrated to have anticancer activity, immune-enhancing effects, wound healing, and antimicrobial activity $(9-11)$. Chitosan-induced cell apoptosis was proposed by caspase- 3 activation, which plays a critical role in the initiation and execution of apoptosis (12). The advantages of this glue are that it is nontoxic and biodegradable, and it induces apoptosis of tumor-like cells. These characteristics make it a promising biomaterial for the treatment of endometriosis. To the best of our knowledge, there is no information in the literature on how PGA/chitosan $(\mathrm{P} / \mathrm{C})$ glue affects endometrial cell growth, or on its application for the treatment of endometriosis.

\section{MATERIALS AND METHODS Culture Media}

Cell culture medium consisted of M199 and F12 (1:1) supplemented with P $(5 \mu \mathrm{g} / \mathrm{mL}$, Sigma, St. Louis, MO), insulintransferrin-sodium selenite medium supplement (ITS), 100 $\mathrm{U}$ penicillin, $0.1 \mathrm{mg}$ of streptomycin, and amphotericin B $(0.25 \mu \mathrm{g} / \mathrm{mL})$. Collagenase (Sigma, St. Louis, MO) was dissolved as a $2-\mathrm{mg} / \mathrm{mL}$ solution in Dulbecco's modified Eagle's medium-high glucose (DMEM-H) medium (Life Technologies, Rockville, MD).

\section{Endometriotic Tissue and Preparation of Primary Endometriotic Cells}

Endometriotic tissue samples were obtained from patients undergoing laparoscopy for unexplained infertility with known endometriosis. Twelve tissue samples were collected at the Department of Obstetrics and Gynecology, Taipei Veterans General Hospital. Before collection of the endometriotic tissues, consent was obtained from each of the donors for analysis of possible molecular diagnosis and utilization. Tissue samples were obtained from the proliferative phase (days 5 14) from women who had received no hormonal therapy within the prior 30 days. Tissue samples (approximately 1-2 g) preserved in DMEM-H transfer medium were transported to the laboratory. The tissue was rinsed in Hanks' balanced salt solution (HBSS) to remove blood and cell debris. After gentle centrifugation at $600 \times g$ for 5 minutes, the tissue was collected and placed into a plastic tissue culture dish (Corning-Costar, Cambridge, MA). Then, the tissue was minced into $1-\mathrm{mm}^{2}$ fragments and digested with collagenase for 2.5 hours at $37^{\circ} \mathrm{C}$. The digested tissue was vigorously pipetted and placed on a stacked sterile wire sieve assembly with a no. 100 wire cloth sieve, followed by a no. 400 wire cloth sieve $(37 \mu \mathrm{m})$. Two types of endometrial cells, glandular epithelium and stroma, were collected by sequential sieves (13). Primary epithelial cells were cultured in $\mathrm{P} / \mathrm{C}$ glue-coated culture plates or noncoated tissue culture polystyrene culture plates containing cell culture medium.

\section{Glue and Culture Plate Preparation}

In this study, we prepared two types of $\mathrm{P} / \mathrm{C}$ glue. Type 1 was named $\mathrm{P} / \mathrm{C}$ glue $\mathrm{A}$, which was prepared by mixing a PGA solution (24\% wt) and a chitosan solution (2\% wt). The other was P/C glue B for which PGA/chitosan films were resolubilized in phosphate-buffered saline (PBS) solution for 1 week; the $\mathrm{pH}$ was adjusted using HBSS. Serial doses of P/C spray A were prepared by dilution with culture media. In the $\mathrm{P} / \mathrm{C}$ glue A group, we sprayed glue $\mathrm{A}$ on the surface of a cell monolayer. In $\mathrm{P} / \mathrm{C}$ glue $\mathrm{B} / \mathrm{A}$ treatment, we sprayed $\mathrm{P} / \mathrm{C}$ glue $\mathrm{B}$ for 30 minutes and then sequentially sprayed glue P/C A on the cell monolayer. Four types of $\mathrm{P} / \mathrm{C}$ glue $\mathrm{A}$ (containing $2,000,1,000,600$, and $100 \mu \mathrm{g} / \mathrm{mL} \mathrm{P} / \mathrm{C}$ glue A) were prepared and sprayed to the surface of the cell monolayer in this study.

\section{Growth Inhibition Assay}

Four types of P/C glue A $(2,000,1,000,600$, and $100 \mu \mathrm{g} / \mathrm{mL})$ were prepared and subjected to cell culture. Aliquots of $2.5 \times$ $10^{5}$ cells $/ \mathrm{mL}$ were seeded in complete culture medium for 24 hours, and then cultured with four types of $\mathrm{P} / \mathrm{C}$ glue $\mathrm{A}$ or $\mathrm{P} / \mathrm{C}$ glue B/A. After 4 days of incubation, treated cells were washed with medium and then subjected to a growth inhibition assay using the cell proliferation assay kit of the WST-1 method (Chemicon International, Temecula, CA). This colorimetric quantification based on the cleavage of the tetrazolium salt, WST-1, by mitochondrial dehydrogenase measured the absorbance by a microplate reader-SpectraMax (Molecular Devices, Sunnyvale, CA) at a $450-\mathrm{nm}$ wavelength. The reference wavelength was $600 \mathrm{~nm}$.

\section{Morphological Analysis of P/C Glue-Treated Cells}

An aliquot of $2.5 \times 10^{5}$ cells was seeded in complete culture medium for 24 hours, and then cultured with four types of $\mathrm{P} / \mathrm{C}$ glue A. After 4 days of incubation, treated cells were washed with medium and then incubated with the fluorescent probes at $37^{\circ} \mathrm{C}$, after which they were visualized using an Olympus Fluoview 2-laser confocal microscope (IX-70, Olympus Optical, Tokyo, Japan). Thus, a combination of nonyl acridine orange (NAO) (14) and propium iodine (PI) (Molecular Probes, Eugene, OR) $(15,16)$ was used for fluorescence imaging analysis of cell viability.

\section{DNA Fragmentation Analysis}

Cells were cultured under monitored conditions for 24 hours, after which the medium was replaced with fresh medium containing various amount of $\mathrm{P} / \mathrm{C}$ glue $\mathrm{A}$ or glue $\mathrm{B}$ and cultured for 72 hours. Treated cells were scraped off and 
(A) Growth-inhibitory effects of endometrial cells cultured with polyglycolic acid/chitosan (P/C) glue A. Endometriotic cells were treated with $100,600,1,000,1,500$, or 2,000 $\mu \mathrm{g} / \mathrm{mL} P / C$ glue $A$, and P/C glue B/A for 4 days, respectively. Reductions in cell viability occurred in a dose-dependent manner after 96 hours of incubation with P/C glue A. (B) A decline in cell viability was revealed for cells cultured on P/C glue $A$ at 500 $\mu \mathrm{g} / \mathrm{mL}$ for 24 to 96 hours.
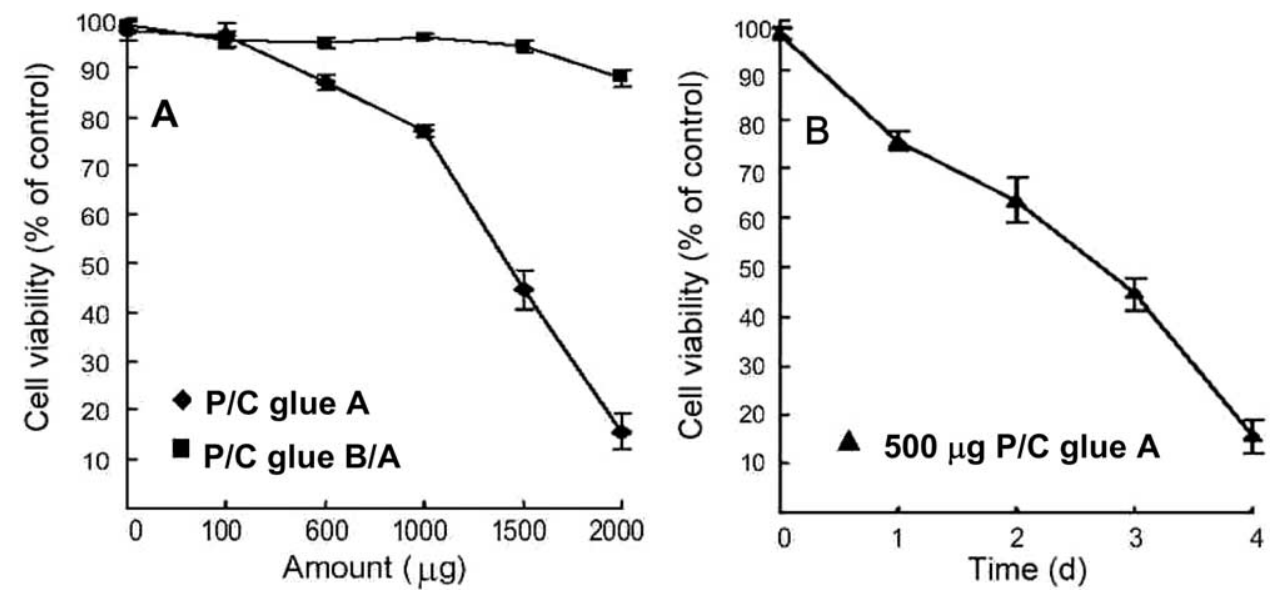

Wang. Apoptosis of endometrial cells. Fertil Steril 2005

prepared for DNA extraction. DNA fragmentation was measured using a Suicide-Track DNA ladder isolation kit (Calbiochem, Darmstadt, Germany). The DNA ladder fragments were separated by electrophoresis on a $1.5 \%$ agarose gel in $1 \times$ TAE buffer at $100 \mathrm{~V}$ for 1 hour and stained with ethidium bromide.

\section{Flow Cytometry}

A combination of fluorescein isothiocyanate conjugate (FITC)-annexin V and PI was also used for simultaneous flow cytometric analysis of the stages of cell apoptosis (15, 16). Cells treated with or without $P / C$ glue $A$ were harvested and washed with PBS. Aliquots of $1 \times 10^{6}$ cells were gently stained with FITC-annexin V and PI in the dark for 15 minutes at room temperature. After staining, cells were washed with PBS and applied to flow cytometric analysis. All analyses were performed by FACScan (Becton Dickson, San Jose, CA) equipped with a single 488-nm argon laser. A minimum of 30,000 cells per sample was analyzed. Debris was gated out based on light-scatter measurements. Data were acquired in the list mode, and the relative proportions of cells within different areas of the fluorescence profile were quantified using the LYSYS II software program (Becton Dickson, Franklin Lakes, NJ).

\section{Assessment of Caspase-3 Activity}

Caspase-3 activities of cell lysates were determined using the "EnzChek" Caspase-3 Activity Assay kit with the ZDEVD-AMC substrate. The fluorescence was detected using a microplate reader-Spectra MAX (Molecular Devices) with an excitation wavelength of $355 \mathrm{~nm}$ and an emission wavelength of $460 \mathrm{~nm}$. All fluorescence was normalized with the soluble protein amount of cell lysate. Protein concentrations were determined with a Bio-Rad Protein Assay reagent (BioRad Laboratories, Hercules, CA). The relative ratio of caspase- 3 activity was defined as the activity of treated cells divided by that of the untreated cells.

\section{RESULTS}

\section{Growth Inhibitory Effect of P/C Glue A}

The reduction in cell viability occurred in a dose-dependent manner after 96 hours of incubation with $\mathrm{P} / \mathrm{C}$ glue A. Cell viability was $95 \%$ in cultures containing $100 \mu \mathrm{g}$ of $\mathrm{P} / \mathrm{C}$ glue $\mathrm{A}$, and less than $15 \%$ in cultures containing $2,000 \mu \mathrm{g}$ of $\mathrm{P} / \mathrm{C}$ glue A (Fig. 1A). In addition, the cell viability was $88 \%$ in cultures containing $\mathrm{P} / \mathrm{C}$ glue $\mathrm{B} / \mathrm{A}$ (treated with $\mathrm{P} / \mathrm{C}$ glue $\mathrm{B}$ for 30 minutes and then treated with $\mathrm{P} / \mathrm{C}$ glue A) (Fig. 1A). The growth inhibitory effect was reduced in cells incubated with $\mathrm{P} / \mathrm{C}$ glue $\mathrm{B} / \mathrm{A}$. The $\mathrm{P} / \mathrm{C}$ glue $\mathrm{B}$ was found to protect cultured cells from growth inhibition by $\mathrm{P} / \mathrm{C}$ glue $\mathrm{A}$.

\section{Induction of Cell Death by P/C Glue A}

Using two fluoresceins, NAO and PI, provided further verification of cell death. The NAO was used to stain the mitochondria of viable cells, whereas DNA staining by PI was used to identify dead cells. The staining pattern of viable cells was NAO-positive and PI-negative, whereas it was NAO-negative and PI-positive in apoptotic or necrotic cells (Fig. 2). The differential staining pattern of treated cell was obtained after 4 days of culture with tissue culture polysty- 
Morphological analysis of endometriosis cells treated with different concentrations of polyglycolic $\mathrm{acid} /$ chitosan $(\mathrm{P} / \mathrm{C})$ glue $\mathrm{A}$ for 4 days. (A) Cells were cultured on tissue culture polystyrene, or (B) cells were treated with $1,000 \mu \mathrm{g} / \mathrm{mL}$, (C) $1,500 \mu \mathrm{g} / \mathrm{mL}$, or (D) $2,000 \mu \mathrm{g} / \mathrm{mL}$ of P/C glue A. After 4 days of incubation, cells were collected and stained with nonyl acridine orange and propium iodine as described in the Materials and Methods section. Photographs were taken at $\times 60$ magnification using an Olympus IX-70 fluorescence microscope.

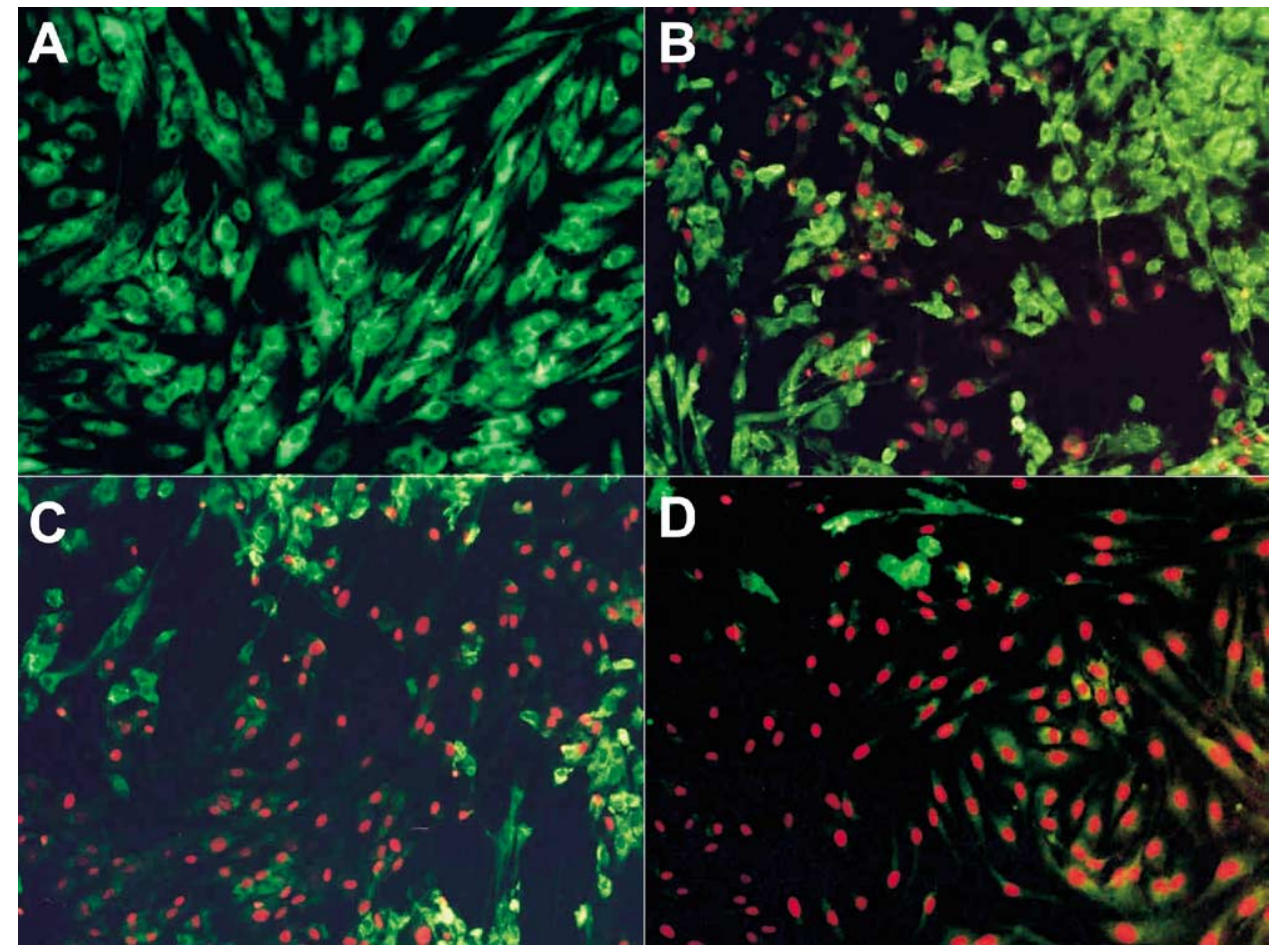

Wang. Apoptosis of endometrial cells. Fertil Steril 2005

rene, and $1,000,1,500$, or $2,000 \mu \mathrm{g} / \mathrm{mL} \mathrm{P} / \mathrm{C}$ glue A. The reduced NAO and increased PI staining patterns were revealed in the $\mathrm{P} / \mathrm{C}$ glue A-treated cells in a dose-response manner. In Figure 2D, most of the cells were stained red, indicating that a large proportion of the endometriotic cells were in the late apoptotic stage after treatment with 2,000 $\mu \mathrm{g} / \mathrm{mL}$ P/C glue A. Furthermore, DNA fragmentation was detected in endometrial cells exposed to 1,000 or 1,500 $\mu \mathrm{g} / \mathrm{mL} \mathrm{P} / \mathrm{C}$ glue A for 4 days (data not shown).

\section{Analysis of Apoptotic Cells by Flow Cytometry}

The staining pattern of viable cells was annexin $\mathrm{V}$-negative and PI-negative, whereas it was annexin V-positive and PI-negative in early apoptotic cells, and both were positive in apoptotic or necrotic cells. The percentages of early apoptotic fractions were $80 \%, 95 \%$, and $82 \%$ with 4,7 , or 8 days of treatment, respectively. Late apoptosis or necrosis was only detectable in the group at 8 days of culture. Induction of apoptosis was reduced when cells were pretreated with P/C glue B (Fig. 3). Percentages of the early apoptotic fractions were $1 \%$ and $3 \%$ of cells treated with $\mathrm{P} / \mathrm{C}$ glue $\mathrm{B} / \mathrm{A}$ for 1 and 4 days, respectively. Cells treated with $\mathrm{P} / \mathrm{C}$ glue $\mathrm{B} / \mathrm{A}$ remained viable.

\section{Caspase-3 Activities}

We examined the affects of caspase- 3 on treated endometriotic cells. After 4 days of treatment, caspase- 3 activity had increased 1.3-fold in 1,000 $\mu \mathrm{g}$ P/C glue A-treated cells (Fig. 4, column 3) compared with cells in the control group (column 1), and 2.2-fold in cells treated with 2,000 $\mu \mathrm{g}$ P/C glue A (column 5). There was no significant difference in caspase-3 activity between cells treated with $\mathrm{P} / \mathrm{C}$ glues B/A (column 7) and the control group. In columns $2,4,6$, and 8 , we added a caspase-3 inhibitor into cells before treatment as in columns 1,3,5, and 7 . Activation of caspase- 3 was diminished by supplementation with the caspase- 3 inhibitor.

According to our data, P/C glue A possibly induced apoptosis through caspase-3 activation in endometriotic cells.

\section{DISCUSSION}

This study reports the novel biological activities of P/C glue. Recently there have been several studies showing that chitosan is widely used in medical and pharmaceutical fields because of its low toxicity and biological effects (17-20). The watersoluble chitosan oligomer (WSCO) appears to have anticancer 
Fluorescein isothiocyanate conjugate (FITC)-annexin $\mathrm{V}$ and propidium iodide (PI) flow cytometry of polyglycolic acid/chitosan $(\mathrm{P} / \mathrm{C})$ glue A-treated and glue B-treated cells. The early apoptotic population with $\mathrm{PI}$-negative and annexin V-positive cells (indicated by open circles) increased on days 4 and 7 .

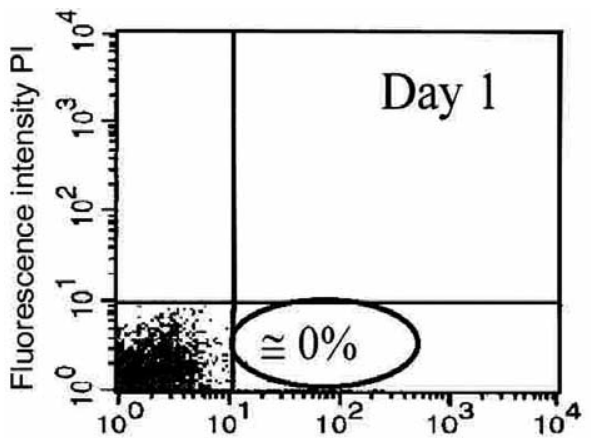

Fluorescence intensity FITC-annexin V

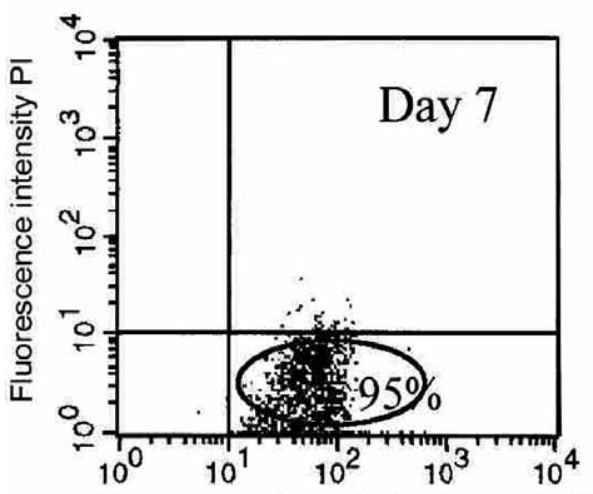

Fluorescence intensity FITC-annexin V

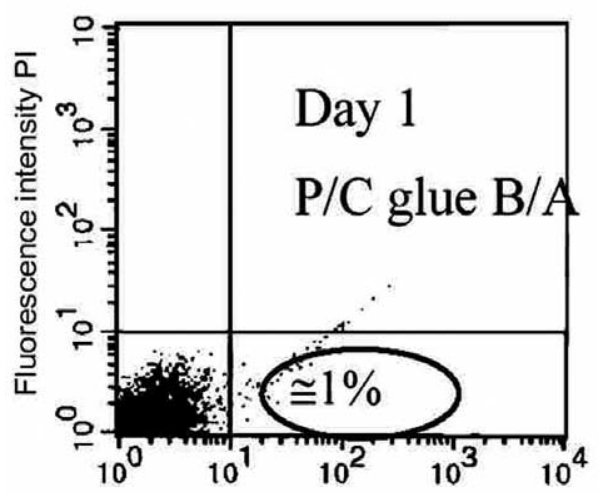

Fluorescence intensity FITC-annexin V

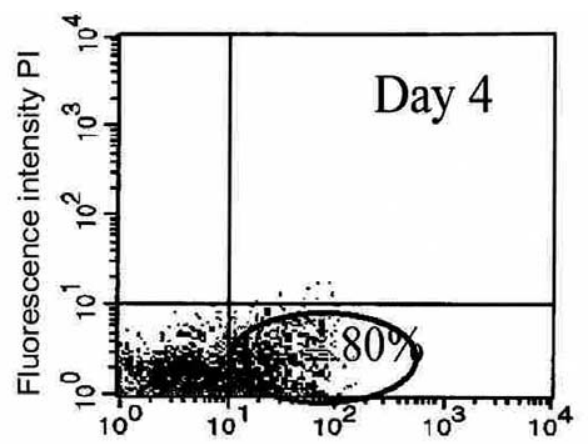

Fluorescence intensity FITC-annexin V

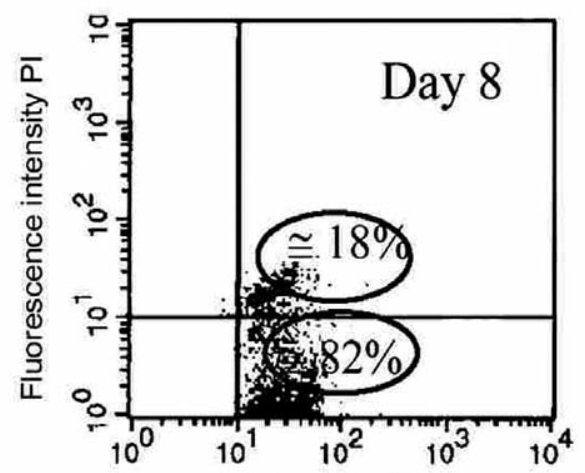

Fluorescence intensity FITC-annexin V

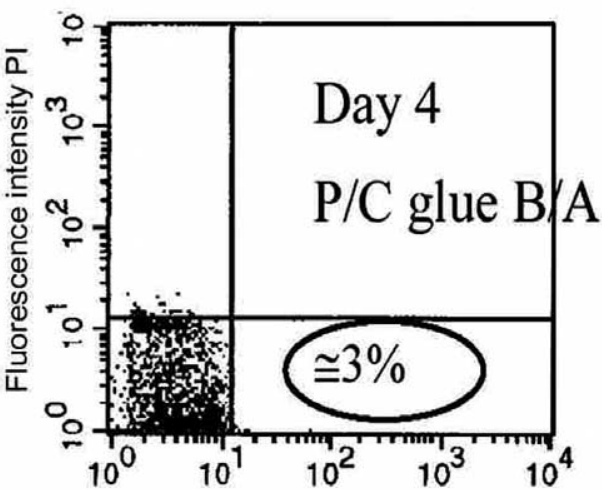

Fluorescence intensity FITC-annexin V

Wang. Apoptosis of endometrial cells. Fertil Steril 2005

activity, immune-enhancing effects, wound healing, and antimicrobial activity $(9-11)$. Furthermore, WSCO is able to inhibit proliferation of human leukemia (HL)-60 cells and induce differentiation of those cells. Previous studies showed that chitosan, as a cationic polymer, interacts with cell membranes, causing lysis of red blood cells and growth inhibition of melanoma cells (21-25). When chitosan is dissolved in solution, the amino groups in the $\mathrm{N}$-deacetylated subunits confer a highly positive charge density. These amino groups have intrinsic $\mathrm{pKa}$ values of 6.5 , and thus, they behave as a polyglycan at both acidic and neutral $\mathrm{pH}$ values (26). Chitosan binds mammalian cells by interacting with surface glycoproteins (27). Based on the characteristics of chitosan, we hypothesized that a possible interaction of the positive charge of chitosan with cell surface proteins leads to ionic changes in cell membranes. This interaction is important in maintaining cell integrity, related functions, and cell growth and differentiation (28).

In our study, we addressed the biological effects of blended glue. Its unique characteristics, such as nontoxicity, 


\section{FIGURE 4}

Caspase-3 activities were determined in polyglycolic acid/chitosan $(\mathrm{P} / \mathrm{C})$ glue A-treated cells. In column $1,1,000 \mu \mathrm{g} / \mathrm{mL}$ of $\mathrm{P} / \mathrm{C}$ glue; column 2, $1,000 \mu \mathrm{g} / \mathrm{mL}$ of $\mathrm{P} / \mathrm{C}$ glue $A$ with a caspase-3 inhibitor; column 3, 1,500 $\mu \mathrm{g} / \mathrm{mL}$ of $\mathrm{P} / \mathrm{C}$ glue $A$; column $4,1,500 \mu \mathrm{g} / \mathrm{mL}$ of $P / C$ glue $A$ with a caspase-3 inhibitor; column $5,2,000 \mu \mathrm{g} / \mathrm{mL}$ of $\mathrm{P} / \mathrm{C}$ glue $\mathrm{A}$; column $6,2,000 \mu \mathrm{g} / \mathrm{mL}$ of $\mathrm{P} / \mathrm{C}$ glue $\mathrm{A}$ with a caspase-3 inhibitor; column $7,2,000 \mu \mathrm{g} / \mathrm{mL}$ of $\mathrm{P} / \mathrm{C}$ glue $\mathrm{B} / \mathrm{A}$, and column $8,2,000 \mu \mathrm{g} / \mathrm{mL} \mathrm{P} / \mathrm{C}$ glue $B / A$ with a caspase-3 inhibitor. Values shown are the mean $( \pm S D)$ of three independent assays performed in triplicate.

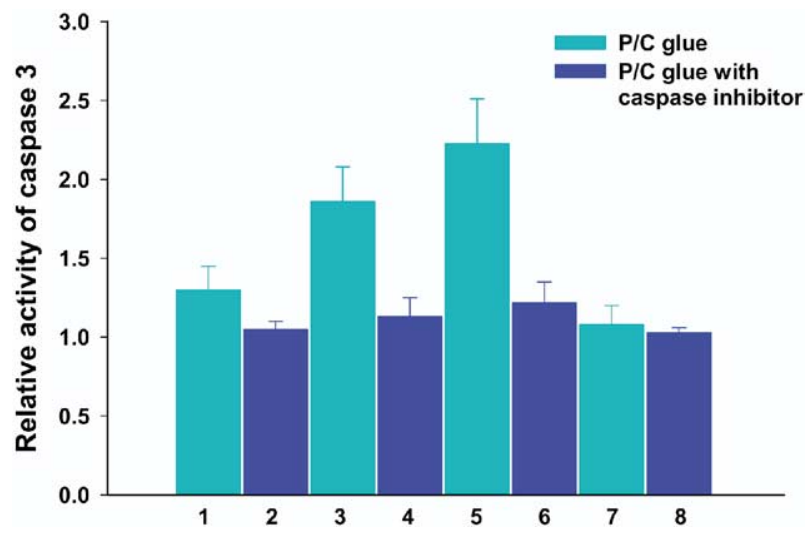

Wang. Apoptosis of endometrial cells. Fertil Steril 2005.

biocompatibility, biodegradability, and changeability, make it a promising biomaterial for clinical use. The blended P/C glue is more biodegradable than pure chitosan, according to our previous study $(29,30)$. In an in vitro degradation study, most of the P/C matrices lost $60 \%$ of their weight as a consequence of natural degradation after 35 days of in vitro culture. At the same time, chitosan only lost $40 \%$ of its weight. Blended PGA may rapidly form hydrogen bonds with water molecules, thus leading to a greater degradation rate (29).

In this study, we demonstrated that $\mathrm{P} / \mathrm{C}$ glue offers growth inhibitory activity in endometriotic cells. This growth inhibition was due to induction of cell apoptosis by P/C glue A. The P/C glue A-treated cells showed nuclear fragmentation and chromatin condensation, which indicate cell apoptosis. DNA showed fragmentation after cells had been treated for 4 days with 2,000 $\mu \mathrm{g}$ of P/C glue A (data not shown). Nearly $80 \%$ of cells treated with $2,000 \mu \mathrm{g}$ of $\mathrm{P} / \mathrm{C}$ glue A for 4 days underwent apoptosis (Fig. 3). Recently many chemotherapeutic agents have been shown to activate apoptotic mechanisms, which lead to drug-induced cell death (31). Activation of caspases plays a crucial role in the biological events associated with apoptosis $(32,33)$. In particular, caspase- 3 is reported to be the executioner, which can cleave the DEVD- substrate into a fluorescent product. As shown in Figure 4, caspase- 3 activity in $\mathrm{P} / \mathrm{C}$ glue-treated cells was significantly elevated. The caspase- 3 activity in the $2,000-\mu \mathrm{g}$ P/C gluetreated cells was increased approximately 2.2 -fold compared to untreated cells. We suggest that the growth inhibitory activity of $\mathrm{P} / \mathrm{C}$ glue $\mathrm{A}$ is by induction of apoptosis through caspase- 3 activation. Caspase- 3 activity was not changed in $\mathrm{P} / \mathrm{C}$ glue B-treated cells. In addition, the growth inhibitory effect of P/C glue A was reduced in cells treated with a caspase- 3 inhibitor, suggesting that caspase- 3 activation is required for $\mathrm{P} / \mathrm{C}$ glue $\mathrm{A}$-induced apoptosis. The $\mathrm{P} / \mathrm{C}$ glue $\mathrm{B}$ may adhere to the cell membrane and evoke a biological change in the cell membrane. This result suggests that $\mathrm{P} / \mathrm{C}$ glue $\mathrm{B}$ might block the interactions of $\mathrm{P} / \mathrm{C}$ glue $\mathrm{A}$ with cell membranes that induce apoptosis.

The P/C glue directly inhibits cell proliferation by inducing caspase-3-mediated apoptosis. Takimoto et al. (12) had previously demonstrated that chitosan induces apoptosis through caspase-3 activation, which leads to activation of caspase- 8 detached from the "death domain," the cytoplasmic sequence of death receptors. Given its molecular size and cationic property, chitosan might not directly enter into the cell, but rather interact with the cell membrane. When exposed to anticancer agents, the majority of endometriosis cells appear to express death receptors such as Fas-Fas ligand (FasL), tumor necrosis factor receptor-1 (TNF-R1), and TNF-related apoptosis-inducing ligand (TRAIL) receptors, which are activated by or participate in the death program $(12,22)$. Chitosan may induce cell death through an interaction with death receptors and sequential activation of the caspase cascade. Moreover, clinically relevant concentrations of diverse anticancer agents such as cisplatin, doxorubicin, mitomycin, and camptothecin, have been shown to induce Fas/FasL expression in a number of cancer cell lines and endometriotic cells (33-35). It is possible that many endometriotic cells not only become resistant to Fas-mediated apoptosis, but also acquire the ability to use this pathway to their advantage by launching a "Fas counter-attack" against the host's immune system (36). Because P/C modulates a death receptor expression and promote endometriotic cells to loss resistant to Fas-caspase-8 - caspase-3-mediated apoptosis.

In our previous study (30), a mixture of PGA and chitosan was prepared using solvents of low toxicity to create novel, biocompatible, degradable, and modifiable hybrid materials. Fibroblast cells cultivated in these materials proliferated. In this study, we also monitored the $\mathrm{pH}$ changes during the $\mathrm{P} / \mathrm{C}$ glue degradation and examined effects caused from the degradable products. We also checked the telomerase activity and $\mathrm{Ki}-67$ level in the $\mathrm{P} / \mathrm{C}$ glue $\mathrm{A}$ - or $\mathrm{P} / \mathrm{C}$ glue $\mathrm{A} / \mathrm{B}$-treated endometriotic cells. None of the cytotoxicity and tumorgenicity was found in the P/C glue-manipulated cells (data not shown).

In the future, studies should be conducted to clarify the second messenger to the apoptosis pathway activated by P/C 
glue $\mathrm{A}$ and measure the effectiveness of $\mathrm{P} / \mathrm{C}$ glue $\mathrm{A}$ alone or in combination with glue $\mathrm{B}$ on endometriosis in animals. We plan to spray $\mathrm{P} / \mathrm{C}$ glue A glue and make a membrane layer to cover the neoplastic endometrial tissue. Before the $\mathrm{P} / \mathrm{C}$ glue A treatment, $\mathrm{P} / \mathrm{C}$ glue $\mathrm{B}$ will be applied into the surrounding normal area and protect the normal tissue. In conclusion, the natural polysaccharide chitosan induces apoptosis in endometriosis and could potentiate the proapoptotic effect of treatment drug. A combination of $\mathrm{P} / \mathrm{C}$ glues $\mathrm{A}$ and $\mathrm{B}$ may be one approach to treat endometriosis.

\section{REFERENCES}

1. Martin DC. Research aspects of endometriosis surgery. Ann NY Acad Sci 2002;955:353-9.

2. Olive DL, Pritts EA. The treatment of endometriosis: a review of the evidence. Ann NY Acad Sci 2002;955:360-72.

3. Olive DL, Pritts EA. Treatment of endometriosis. N Engl J Med 2001;345:266-75.

4. Gambone JC, Mittman BS, Munro MG, Scialli AR, Winkel CA. Consensus statement for the management of chronic pelvic pain and endometriosis: proceedings of an expert-panel consensus process. Fertil Steril 2002;78:961-72.

5. Ueda M, Yamashita Y, Takehara M, Terai Y, Kumagai K, Ueki K, et al. Survivin gene expression in endometriosis. J Clin Endocrinol Metab 2002;87:3452-9.

6. Peiro G, Diebold J, Buretton GB, Kimmig R, Lohrs U. Cellular apoptosis susceptibility gene expression in endometrial carcinoma: correlation with Bcl-2, Bax, and Caspase-3 expression and outcome. Int J Gynecol Pathol 2001;20:359-67.

7. Athanasiou KA, Niederauer GG, Agrawal CM. Sterilization, toxicity, biocompatibility and clinical applications of polylactic acid/polyglycolic acid copolymers. Biomaterials 1996;17:93-102.

8. Murphy WL, Kohn DH, Mooney DJ. Growth of continuous bonelike mineral within porous poly(lactide-co-glycolide) scaffolds in vitro. J Biomed Mater Res 2000;50:50-8.

9. Hasegawa M, Yagi K, Iwakawa S, Hirai M. Chitosan induces apoptosis via caspase-3 activation in bladder tumor cells. Jpn J Cancer Res 2001;92:459-66.

10. Ueno H, Mori T, Fujinaga T. Topical formulations and wound healing applications of chitosan. Adv Drug Deliv Rev 2001;52:105-15.

11. Sabnis S, Block LH. Chitosan as an enabling excipient for drug delivery systems. I. Molecular modifications. Int J Biol Macromol 2000;13: $181-6$.

12. Takimoto H, Hasegawa M, Yagi K, Nakamura T, Sakaeda T, Hirai M. Proapoptotic effect of a dietary supplement: water soluble chitosan activates caspase- 8 and modulating death receptor expression. Drug Metab Pharmacokinet 2004;19:76-82.

13. Arnold JT, Kaufman DG, Seppala M, Lessey BA. Endometrial stromal cells regulate epithelial cell growth in vitro: a new co-culture model. Hum Reprod 2001;16:836-45.

14. Keij JF, Bell-Prince C, Steinkamp JA. Staining of mitochondrial membranes with 10-nonyl acridine orange, MitoFluor Green, and MitoTracker Green is affected by mitochondrial membrane potential altering drugs. Cytometry 2000;39:203-10.

15. Vermes I, Haanen C, Reutelingsperger C. Flow cytometry of apoptotic cell death. J Immunol Methods 2000;243:167-90.

16. van Engeland M, Nieland LJ, Ramaekers FC, Schutte B, Reuteling- sperger CP. Annexin V-affinity assay: a review on an apoptosis detection system based on phosphatidylserine exposure. Cytometry 1998;31:1-9.

17. Suh JK, Matthew HW. Application of chitosan-based polysaccharide biomaterials in cartilage tissue engineering: a review. Biomaterials 2000;21:2589-98.

18. Singla AK, Chawla M. Chitosan: some pharmaceutical and biological aspects_an update, J Pharm Pharmacol 2001;53:1047-67.

19. van der Lubben IM, Verhoef JC, Borchard G, Junginger HE. Chitosan and its derivatives in mucosal drug and vaccine delivery. Eur J Pharm Sci 2001;14:201-7.

20. Peh K, Khan T, Ch'ng H. Mechanical, bioadhesive strength and biological evaluations of chitosan films for wound dressing. J Pharm Pharm Sci 2000;3:303-11.

21. Loke WK, Lau SK, Yong LL, Khor E, Sum CK. Wound dressing with sustained anti-microbial capability. J Biomed Mater Res 2000;53:8-17.

22. Hasegawa M, Yagi K, Iwakawa S, Hirai M. Chitosan induces apoptosis via caspase-3 activation in bladder tumor cells. Jpn J Cancer Res 2001;92:459-66.

23. Risbud M, Bhonde M, Bhonde R. Chitosan-polyvinyl pyrrolidone hydrogel does not activate macrophages: potentials for transplantation applications. Cell Transplant 2001;10:195-202.

24. Pae HO, Seo WG, Kim NK, Oh GS, Kim GE, Kim YH, et al. Induction of granulocytic differentiation in acute promyelocytic leukemia cells (HL-60) by water-soluble chitosan oligomer. Leuk Res 2001;25:339-46.

25. Artursson P, Lindmark T, Davis SS, Illum L. Effect of chitosan on the permeability of monolayers of intestinal epithelial cells (Caco-2). Pharm Res 1994;11:1358-61.

26. Schipper NG, Varum KM, Artursson P. Chitosans as absorption enhancers for poorly absorbable drugs. 1: Influence of molecular weight and degree of acetylation on drug transport across human intestinal epithelial (Caco-2) cells. Pharm Res 1996;13:1686-92.

27. MacLaughlin FC, Mumper RJ, Wang J, Tagliaferri JM, Gill I, Hinchcliffe $\mathrm{M}$, et al. Chitosan and depolymerized chitosan oligomers as condensing carriers for in vivo plasmid delivery. J Control Release 1998;56:259-72.

28. Santini MT, Cametti C, Indovina PL, Morelli G, Donelli G. Polylysine induces changes in membrane electrical properties of K562 cells. J Biomed Mater Res 1997;35:165-74.

29. Wang YC, Lin MC, Hsieh HJ. Fabrication and characterization of a novel polyglycolic acid biomaterial for tissue engineering. Biomaterials 2003;24:1047-57.

30. Wang YC, Kao SH, Hsieh HJ. A chemical surface modification of chitosan by glycoconjugates to enhance the cell-biomaterial interaction. Biomacromolecules 2003;4:224-31.

31. Makin G. Targeting apoptosis in cancer chemotherapy. Expert Opin Ther Targets 2002;6:73-84.

32. Thornberry NA, Lazebnik Y. Caspases: enemies within. Science 1998; 281:1312-6.

33. Debatin K. Activation of apoptosis pathways by anticancer treatment. Toxicol Lett 2000;112-113:41-8.

34. Garcia-Velasco JA, Mulayim N, Kayisli UA, Arici A. Elevated soluble Fas ligand levels may suggest a role for apoptosis in women with endometriosis. Fertil Steril 2002;78:855-9.

35. Fauvet R, Poncelet C, Hugol D, Lavaur A, Feldmann G, Darai E. Expression of apoptosis-related proteins in endometriomas and benign and malignant ovarian tumours. Virchows Arch 2003;443:38-43.

36. Harada T, Kaponis A, Iwabe T, Taniguchi F, Makrydimas G, Sofikitis $\mathrm{N}$, et al. Apoptosis in human endometrium and endometriosis. Hum Reprod Update 2004;10:29-38. 